\title{
Cover plants with potential use for crop-livestock integrated systems in the Cerrado region
}

\author{
Arminda Moreira de Carvalho(1), Lara Line Pereira de Souza(2), Roberto Guimarães Júnior ${ }^{(1)}$, \\ Pedro Cesar Almeida Castro Alves ${ }^{(1)}$ and Lúcio José Vivaldi(3)
}

\begin{abstract}
(1)Embrapa Cerrados, BR 020, Km 18, Caixa Postal 08223, CEP 73310-970 Planaltina, DF, Brazil. E-mail: arminda@cpac.embrapa.br, guimaraes@cpac.embrapa.br, pedrocesaraca@uol.com.br (2)Secretaria de Agricultura, Pecuária e Abastecimento do Distrito Federal, SAIN Parque Rural, Edifício Sede CEP 70620-000 Brasília, DF, Brazil. E-mail: laralinepereira@yahoo.com.br ${ }^{(3)}$ Universidade de Brasília, Campus Darcy Ribeiro, CEP 70910-900 Brasília, DF, Brazil. E-mail: vivaldi@unb.br
\end{abstract}

\begin{abstract}
The objective of this work was to evaluate the effects of lignin, hemicellulose, and cellulose concentrations in the decomposition process of cover plant residues with potential use in no-tillage with corn, for crop-livestock integrated system, in the Cerrado region. The experiment was carried out at Embrapa Cerrados, in Planaltina, DF, Brazil in a split plot experimental design. The plots were represented by the plant species and the subplots by harvesting times, with three replicates. The cover plants Urochloa ruziziensis, Canavalia brasiliensis, Cajanus cajan, Pennisetum glaucum, Mucuna aterrima, Raphanus sativus, Sorghum bicolor were evaluated together with spontaneous plants in the fallow. Cover plants with lower lignin concentrations and, consequently, higher residue decomposition such as $C$. brasiliensis and $U$. ruziziensis promoted higher corn yield. High concentrations of lignin inhibit plant residue decomposition and this is favorable for the soil cover. Lower concentrations of lignin result in accelerated plant decomposition, more efficient nutrient cycling, and higher corn yield.
\end{abstract}

Index terms: chemical composition, organic matter, corn yield.

\section{Plantas de cobertura com potencial de uso para a integração lavoura-pecuária na região do Cerrado}

\begin{abstract}
Resumo - O objetivo deste trabalho foi avaliar os efeitos de concentrações de lignina, hemicelulose e celulose na decomposição de resíduos vegetais de plantas de cobertura, com potencial de uso em plantio direto com milho, em sistema de integração lavoura-pecuária, na região do Cerrado. $\mathrm{O}$ experimento foi conduzido na Embrapa Cerrados, Planaltina, DF, em parcelas subdivididas. As plantas de cobertura representaram as parcelas, e a época de colheita representou as subparcelas, com três repetições. Avaliaram-se as espécies de plantas de cobertura Urochloa ruziziensis, Canavalia brasiliensis, Cajanus cajan, Pennisetum glaucum, Mucuna aterrima, Raphanus sativus, Sorghum bicolor, bem como as plantas espontâneas em pousio. Plantas de cobertura com menores concentrações de lignina e, consequentemente, com maiores taxas de decomposição de resíduos vegetais como C. brasiliensis e U. ruziziensis promoveram maior produtividade de milho. Concentrações elevadas de lignina inibem a decomposição dos resíduos vegetais e isso é favorável a cobertura do solo. As menores concentrações de lignina resultam em decomposição acelerada de resíduos vegetais, ciclagem mais efetiva de nutrientes e maior produtividade de milho.
\end{abstract}

Termos para indexação: composição química, matéria orgânica, produtividade de milho.

\section{Introduction}

The basic uses of cover crops include protecting the soil against erosion, increasing soil organic matter, improving soil quality, promoting carbon-sequestration, enabling producers to use less water and fertilizers and to control weeds. Cover crops are also more efficient at nutrient cycling and play an important role as a component of the no-tillage system (Machado \& Silva, 2001; Diekow et al., 2005; Hollinger, 2005; Costa et al., 2008). In crop-livestock integrated systems, cover plants improve soil physicochemical and biological properties (Marchão et al., 2009), contribute to recover degraded pastures and areas, and have positive impacts on soil quality (Lal, 2002). Some cover plants, such as Cajanus cajan, Sorghum bicolor and Pennisetum glaucum, can improve the quality of animal feed. The selection of plant species for use as cover crops depends on the plant ability to adapt to climate and soil, as well as on the interest of the producer (Araújo \& Almeida, 1993; Wutke et al., 2009). Maintaining crop residues on the soil surface protects the soil and enables a more

Pesq. agropec. bras., Brasília, v.46, n.10, p.1200-1205, out. 2011 
efficient nutrient cycling (Muhr et al., 1999; Pitol et al., 2006; Machado \& Assis, 2010).

Biotic and abiotic factors, such as microorganisms, harvesting periods, plant flowering and maturation, air and soil temperatures, rainfall distribution, soil humidity, and the chemical composition of crop residues $(\mathrm{C} / \mathrm{N}$, lignin, hemicellulose, and cellulose) affect the biomass production, decomposition rates and the establishment of coverage on the soil surface (Araújo \& Almeida, 1993; Aita \& Giacomini, 2003; Sodré Filho et al., 2004; Carvalho et al., 2008, 2009).

In the Cerrado region, some grasses such as $P$. glaucum are more cultivated as cover crops, due to their higher drought tolerance and biomass production, as well as the lower costs of their seeds (Lara Cabezas et al., 2004; Pacheco et al., 2011). Urochloa ruziziensis adapts easily and well to Cerrado's low fertility soils and climate, shows a high biomass production rate along the year and functions as an efficient soil cover. However, studies on its use as a cover crop are scarce.

Despite the advantages of using leguminous plants as soil coverage (Elfstrand et al., 2007; Wutke et al., 2009), which include the ability to use nitrogen from atmosphere, the presence of deep root systems and a high biomass production, the low $\mathrm{C} / \mathrm{N}$ ratio of the tissues of leguminous plants favors the decomposition process and limits the establishment of soil coverage. However, plant species which show a higher $\mathrm{C} / \mathrm{N}$ ratio, have lower plant residue decomposition rates, and consequently, are more efficient as soil coverage (Carvalho et al., 2008, 2009).

The objective of this study was to evaluate the effects of lignin, hemicellulose, and cellulose concentrations in the decomposition process of cover plant residues with potential use in no-tillage with corn, for crop-livestock integrated system, in the Cerrado region in Brazil.

\section{Materials and Methods}

The experiment was carried out at Embrapa

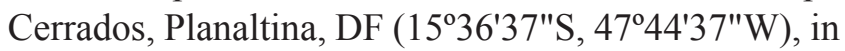
the Central West region of Brazil. Corn was cultivated in an area followed by cover plants planted at the end of the rainy season, in the first year, and this system was repeated during the second year. The soil of the region is classified as Typic Acrustox - Latossolo Vermelho, according to the Brazilian soil classification
(Santos et al., 2006). The area is located within the morphoclimatic domain of Cerrado. The climate is Aw, tropical with rainy summer, according to the classification of Köppen. In this region, the average annual rainfall oscillates between 1,400 and 1,600 mm, and the average annual air temperature varies between 22 and $27^{\circ} \mathrm{C}$ (Adámoli et al., 1987).

The experiment began in February 2008, and the evaluations were performed until March 2009. The plant species used as cover crops were: Canavalia brasiliensis (Mart. ex Benth), Fabaceae, Cajanus cajan (L.) Millsp., Fabaceae, Mucuna aterrima (Piper \& Tracy) Fabaceae, Raphanus sativus (L.), Brassicaceae, Urochloa ruziziensis (R. Germ. \& Evrard), Poaceae, Pennisetum glaucum (L.) R. Brown, Poaceae, and Sorghum bicolor (L. Moench), Poaceae. The control treatment consisted of natural fallow.

The experimental design consisted of split plots, which were represented by plant species and subplots, which were represented by harvesting times (cut at flowering and at maturation), with three replicates.

The analyses of dry matter at $105^{\circ} \mathrm{C}$, acid-detergent fiber (ADF), neutral-detergent fiber (NDF), and lignin were performed with the sequential method (Robertson \& Van Soest, 1981). The concentrations of hemicellulose and cellulose were determined by the differences between NDF and ADF, and between ADF and lignin, respectively.

Decomposition of plant residues was determined by using 20x20 cm nylon bags with 2x2 mm sized meshes containing $10 \mathrm{~g}$ of cut plant residues, which were oven-dried at $65^{\circ} \mathrm{C}$ for 72 hours. The nylon bags were removed from the experimental area at 30, 90, 150, 180 and 210 days after having been placed on the soil, and the material was weighed and oven-dried at $65^{\circ} \mathrm{C}$ for 72 hours once again. After this, the oven-dried material was put in porcelain crucibles and placed in a muffle furnace at $600^{\circ} \mathrm{C}$ for at least eight hours, in order to obtain the final inorganic material.

The decomposition rate, for each period, was calculated according to Santos \& Whitford (1981). Based on the decomposition percentage, the rate of the remaining plant residues on the soil was determined as the difference between the total initial amount of residues $(100 \%)$ and each of the decomposition rates. The data were adjusted to the simple linear regression model $(\mathrm{Y}=\mathrm{ax}+\mathrm{b})$, with the rate of the remaining residues as a function of the accumulated rainfall,

Pesq. agropec. bras., Brasília, v.46, n.10, p.1200-1205, out. 2011 
for each evaluation period, and transformed into a base-10 logarithm.

Analysis of variance with repeated measures (ANOVA) was applied to evaluate the effects of plant species (plots), the effects of cover crops cut times (subplots) and the interaction between these two factors (SAS Institute, 1999). The test of multiple comparisons of averages (Tukey-Kramer at 5\% probability) was applied to the treatments and to the interactions showing significance.

\section{Results and Discussions}

On average, cover crops cut at flowering had higher concentrations of hemicellulose and lignin. Cover crops cut at the end of their cycle (at maturation) showed higher concentrations of cellulose (Table 1). There was a significant interaction between cover plants and harvesting periods (Table 2). Cajanus cajan and $M$. aterrima had the lowest contents of lignin at maturation, probably due to the higher concentrations of protein and to the diluting effect of the nonfibrous carbohydrates in the grains. Pennisetum glaucum, however, had the highest concentration of lignin in the tissues at maturation, due to lower grain yield during the harvest period. Urochloa ruziziensis, C. brasiliensis, M. aterrima, $R$. sativus

Table 1. Effect of harvesting period on hemicellulose, cellulose and lignin concentrations (\%) of cover plants ${ }^{(1)}$.

\begin{tabular}{lccc}
\hline Harvesting period & Hemicellulose & Cellulose & Lignin \\
\hline Flowering & $22.11 \mathrm{a}$ & $10.65 \mathrm{~b}$ & $11.57 \mathrm{a}$ \\
Maturation & $19.48 \mathrm{~b}$ & $14.72 \mathrm{a}$ & $7.05 \mathrm{~b}$ \\
\hline
\end{tabular}

${ }^{(1)}$ Means followed by the same letters, in the column, do not differ by Tukey-Kramer test, at 5\% probability. and natural fallow did not show differences in lignin concentration, in the plant tissue, at flowering and maturation. The maturation of the plants led to higher concentrations of cell wall fibers, lignification and cell wall thickening and, consequently, to a greater resistance to decomposition (Wagner \& Wolf, 1999) (Table 3).

Cajanus cajan had higher concentrations of lignin at flowering (Table 2), which explains the lower decomposition rate of plant residues (Table 3) in comparison to the other studied plant species (Carvalho et al., 2008, 2009). A significantly higher concentration of lignin was also observed in the samples of $M$. aterrima, which were cut during flowering. When cut during maturation, P. glaucum had significantly higher plant tissue lignin concentrations, which explains the slower decomposition rate of plant residues at this stage of development. Despite its high hemicellulose concentrations, S. bicolor, had a slow decomposition rate due to its high $\mathrm{C} / \mathrm{N}$ ratio. Urochloa ruziziensis and C. brasiliensis had significantly lower concentrations of lignin in plant tissue and faster residue decomposition rates, thus confirming the relation between lignin concentration and the decomposition process (Carvalho et al., 2008, 2009).

Cover plants with the lowest lignin concentrations and, consequently, faster residue decomposition rates, such as $C$. brasiliensis, $U$. ruziziensis and $P$. glaucum, contributed to higher corn yields (Table 4). However, cover plants with higher concentrations of lignin, such as C. cajan, S. bicolor and $M$. aterrima, had slower crop residue decomposition rates and promoted lower yields of corn planted in succession. The high quantity of

Table 2. Hemicelluloses, cellulose and lignin concentrations (\%) in cover plants cut at flowering and maturation ${ }^{(1)}$.

\begin{tabular}{|c|c|c|c|c|c|c|}
\hline \multirow[t]{2}{*}{ Cover plant } & \multicolumn{2}{|c|}{ Hemicellulose } & \multicolumn{2}{|c|}{ Cellulose } & \multicolumn{2}{|c|}{ Lignin } \\
\hline & Flowering & Maturation & Flowering & Maturation & Flowering & Maturation \\
\hline Urochloa ruziziensis & $27.53 \mathrm{aA}$ & $25.60 \mathrm{aA}$ & $10.95 \mathrm{bA}$ & $11.38 \mathrm{bA}$ & $3.67 \mathrm{dA}$ & $2.64 \mathrm{bA}$ \\
\hline Canavalia brasiliensis & $18.30 \mathrm{cA}$ & $15.87 \mathrm{bA}$ & $9.85 \mathrm{bcB}$ & $16.90 \mathrm{abA}$ & $7.37 \mathrm{cdA}$ & $3.49 \mathrm{bA}$ \\
\hline Cajanus cajan cv. Mandarim & $20.93 \mathrm{bcA}$ & $16.84 \mathrm{bB}$ & $9.07 \mathrm{bcA}$ & $13.15 \mathrm{bA}$ & $32.18 \mathrm{aA}$ & $7.55 \mathrm{abB}$ \\
\hline Mucuna aterrima & $12.18 \mathrm{dA}$ & $10.81 \mathrm{cA}$ & $4.10 \mathrm{cB}$ & $18.69 \mathrm{aA}$ & $15.77 \mathrm{bA}$ & $5.89 \mathrm{abB}$ \\
\hline Natural fallow & $24.31 \mathrm{abA}$ & $16.56 \mathrm{bB}$ & $10.86 \mathrm{bA}$ & $10.99 \mathrm{bA}$ & $9.13 \mathrm{cdA}$ & $9.42 \mathrm{aA}$ \\
\hline Pennisetum glaucum & $29.87 \mathrm{aA}$ & $27.64 \mathrm{aA}$ & $22.44 \mathrm{aA}$ & $12.96 \mathrm{bA}$ & $4.70 \mathrm{cdB}$ & $10.56 \mathrm{aA}$ \\
\hline Raphanus sativus L. & $17.60 \mathrm{cA}$ & $14.54 \mathrm{bcA}$ & $8.50 \mathrm{bcB}$ & $18.99 \mathrm{aA}$ & $9.43 \mathrm{cA}$ & $10.63 \mathrm{aA}$ \\
\hline Sorghum bicolor & $26.15 \mathrm{aA}$ & $27.94 \mathrm{aA}$ & $9.45 \mathrm{bcA}$ & $14.71 \mathrm{abA}$ & $10.32 \mathrm{bcA}$ & $6.21 \mathrm{abA}$ \\
\hline $\mathrm{CV}(\%)$ & \multicolumn{2}{|c|}{9.1} & \multicolumn{2}{|c|}{26.0} & \multicolumn{2}{|c|}{37.1} \\
\hline
\end{tabular}

${ }^{(1)}$ Means followed by the same letters, lower case in the columns and upper case in the rows, do not differ by Tukey-Kramer test at $5 \%$ probability. 
biomass, produced by C. brasiliensis, may also have favored the greater corn yield, because it accumulated large quantities of $\mathrm{N}$ in its aerial parts and this led to a higher release of nutrients, especially nitrogen (Muhr et al., 1999; Carvalho et al., 2008). Despite S. bicolor high biomass production (Table 4), its low decomposition rate of residues led to competition for nitrogen, and this decreased corn yield which had been planted in succession.

The data of lignin, hemicellulose and cellulose concentrations are complementary to the biomass production, which is an important information when choosing a cover plant for an integrated production system (Carvalho et al., 2008, 2009; Machado \& Assis, 2010; Pacheco et al., 2011). Data on the quality of lignin, cellulose and hemicellulose and the quantity of biomass should support the producer decision-making process, as well as the choice regarding the best plant which will make up the no-till integrated production system (Machado \& Silva, 2001). The use of $C$. brasiliensis and $U$. ruziziensis probably led to a more efficient nutrient cycling, and this increased corn yield in the crop-livestock integrated system (Carvalho et al., 2009; Marchão et al., 2009). In the case of an integrated system with soybean, which has a fast decomposition rate, cover plants with slower decomposition rates, such as C. cajan and S. bicolor, can be used in order to increase the carbon-sequestration of the soil (Silva et al., 1994; Hollinger et al., 2005; Costa et al., 2008).

The use of cover plants is essential for the sustainability of crop systems, especially in crop-livestock integrated systems on highly weathered soils and dry tropical climates as is found in the Cerrado region (Muhr et al., 1999; Machado \& Silva, 2001; Lal, 2002, Pitol et al., 2006; Marchão et al., 2009; Machado \& Assis, 2010).

Under the no-tillage system, C. cajan, S. bicolor, $P$. glaucum, and $M$. aterrima are suitable species for soil cover by plant residues as they fulfill an essential condition, due to their higher proportion of lignin and, consequently, lower decomposition rates (Carvalho et al., 2008, 2009). Nonetheless, for faster nutrient cycling, $U$. ruziziensis, $C$. brasiliensis, and $R$. sativus should be used because of their higher decomposition rates and, consequently, their contribution to increase the crop production in integrated systems.

Table 3. Decomposition process of plant residues harvested at flowering (A) and at maturation (B) in function of the accumulated rainfall quantity.

\begin{tabular}{|c|c|c|c|c|c|c|c|}
\hline \multirow[t]{2}{*}{ Cover plant } & \multicolumn{5}{|c|}{ Accumulated rainfall quantity $(\mathrm{mm})^{(1)}$} & \multirow[t]{2}{*}{ Regression } & \multirow[t]{2}{*}{$\mathrm{R}^{2}$} \\
\hline & 34.6 & 100.9 & 520.3 & 861.4 & $1,128.4$ & & \\
\hline \multicolumn{8}{|c|}{ Rate of remaining residues at flowering (\%) } \\
\hline Cajanus cajan cv. Mandarim & 55.35 & 45.21 & 29.66 & 24.88 & 22.32 & $y=-21.826 x+88.94$ & $0.76^{*}$ \\
\hline Canavalia brasiliensis & 46.39 & 33.99 & 14.99 & 9.15 & 6.02 & $y=-26.675 x+87.445$ & $0.93^{* *}$ \\
\hline Mucuna aterrima & 46.40 & 35.70 & 19.31 & 14.27 & 11.57 & $y=-23.011 x+81.819$ & $0.97 * *$ \\
\hline Natural fallow & 45.84 & 37.55 & 24.84 & 20.93 & 18.84 & $y=-17.843 x+73.3$ & $0.98 * *$ \\
\hline Pennisetum glaucum & 59.53 & 45.21 & 23.26 & 16.52 & 12.90 & $y=-30.811 x+106.95$ & $0.96^{* *}$ \\
\hline Raphanus sativus $\mathrm{L}$. & 35.64 & 28.90 & 18.56 & 15.38 & 13.68 & $y=-14.515 x+57.98$ & $0.81 * *$ \\
\hline Sorghum bicolor & 55.40 & 43.90 & 26.27 & 20.85 & 17.95 & $y=-24.749 x+93.495$ & $0.92 * *$ \\
\hline Urochloa ruziziensis & 46.22 & 33.59 & 14.24 & 8.29 & 5.10 & $y=-27.168 x+88.037$ & $0.98 * *$ \\
\hline \multicolumn{8}{|c|}{ Rate of remaining residues at maturation (\%) } \\
\hline Cajanus cajan cv. Mandarim & 48.24 & 42.54 & 33.80 & 31.11 & 29.67 & $y=-12.266 x+67.119$ & $0.76^{*}$ \\
\hline Canavalia brasiliensis & 27.74 & 22.19 & 13.68 & 11.06 & 9.66 & $y=-11.946 x+46.125$ & $0.93 * *$ \\
\hline Mucuna aterrima & 35.80 & 29.31 & 19.35 & 16.29 & 14.65 & $y=-13.977 x+57.318$ & $0.83^{*}$ \\
\hline Natural fallow & 48.51 & 37.22 & 19.92 & 14.61 & 11.76 & $y=-24.284 x+85.88$ & $0.99 * *$ \\
\hline Pennisetum glaucum & 53.41 & 42.57 & 25.95 & 20.84 & 18.11 & $y=-23.324 x+89.303$ & $0.93 * *$ \\
\hline Raphanus sativus L. & 53.61 & 42.60 & 25.73 & 20.55 & 17.77 & $y=-23.676 x+90.04$ & $0.90^{* *}$ \\
\hline Sorghum bicolor & 50.99 & 42.72 & 30.03 & 26.13 & 24.05 & $y=-17.805 x+78.392$ & $0.85^{* *}$ \\
\hline Urochloa ruziziensis & 32.40 & 25.24 & 14.26 & 10.89 & 9.09 & $y=-15.407 x+56.116$ & $0.78 *$ \\
\hline
\end{tabular}


Table 4. Production of dry matter of cover plants and corn yield ${ }^{(1)}$.

\begin{tabular}{lcc}
\hline Cover plant & Dry matter & $\begin{array}{c}\text { Corn yield } \\
\text {------------- }\left(\mathrm{Mg} \mathrm{ha}^{-1}\right)\end{array}$ \\
\hline Urochloa ruziziensis & $4.51 \mathrm{bc}$ & $9.12 \mathrm{ab}$ \\
Canavalia brasiliensis & $7.57 \mathrm{a}$ & $9.29 \mathrm{a}$ \\
Cajanus cajan cv. Mandarim & $4.69 \mathrm{bc}$ & $7.79 \mathrm{c}$ \\
Mucuna aterrima & $8.17 \mathrm{a}$ & $7.99 \mathrm{bc}$ \\
Natural fallow & $2.87 \mathrm{~cd}$ & $8.54 \mathrm{abc}$ \\
Pennisetum glaucum & $6.75 \mathrm{a}$ & $8.85 \mathrm{abc}$ \\
Raphanus sativus $\mathrm{L}$. & $1.80 \mathrm{~d}$ & $8.43 \mathrm{abc}$ \\
Sorghum bicolor & $6.63 \mathrm{ab}$ & $7.69 \mathrm{c}$ \\
\hline CV $(\%)$ & 16.8 & 5.6 \\
\hline
\end{tabular}

${ }^{(1)}$ Means followed by the same letters, in the column, do not differ by TukeyKramer test, at $5 \%$ probability.

\section{Conclusions}

1. Low concentrations of lignin present in Urochloa ruziziensis and Canavalia brasiliensis accelerate plant residue decomposition, higher nutrient cycling and higher corn yields.

2. High concentrations of lignin present in Cajanus cajan inhibit the decomposition of plant residues, favoring the establishment of soil coverage.

\section{References}

ADÁMOLI, J.; MACEDO, J.; AZEVEDO, L.G.; NETTO, J.M. Caracterização da região dos Cerrados. In: GOEDERT, W.J. (Ed.). Solos dos Cerrados: tecnologias e estratégias de manejo. Planaltina: Embrapa-CPAC; São Paulo: NOBEL, 1987. p.33-98.

AITA, C.; GIACOMINI, S.J. Decomposição e liberação de nitrogênio de resíduos culturais de plantas de cobertura de solo solteiras e consorciadas. Revista Brasileira de Ciência do Solo, V.27, p.601-612, 2003.

ARAÚJO, A.P.; ALMEIDA, D.L. de. Adubação verde associada a fosfato de rocha na cultura de milho. Pesquisa Agropecuária Brasileira, v.28, p.245- 251, 1993.

CARVALHO, A.M. de; BUSTAMANTE, M.M. da C.; ALCÂNTARA, F.A. de; RESCK, I.S.; LEMOS, S.S. Characterization by solid-state CPMAS ${ }^{13} \mathrm{C}$ NMR spectroscopy of decomposing plant residues in conventional and no-tillage systems in central Brazil. Soil and Tillage Research, v.102, p.144-150, 2009.

CARVAlHO, A.M. de; BUSTAMANTE, M.M. da C.; SOUZA JUNIOR, J.G. de A.; VIVALDI, L.J. Decomposição de resíduos vegetais em Latossolo sob cultivo de milho e plantas de cobertura.

Revista Brasileira de Ciência do Solo, v.32, p.2831-2838, 2008.

COSTA, F. de S.; BAYER, C.; ZANATTA, J.A.; MIELNICZUK, J. Estoque de carbono orgânico no solo e emissões de dióxido de carbono influenciadas por sistemas de manejo no Sul do Brasil. Revista Brasileira de Ciência do Solo, v.32, p.323-332, 2008.
DIEKOW, J.; MIELNICZUK, J.; KNICKER, H.; BAYER, C.; DICK, D.P.; KOGEL-KNABNER, I. Soil C and N stocks as affected by cropping systems and nitrogen fertilisation in a Southern Brazil Acrisol managed under no-tillage for 17 years. Soil and Tillage Research, v.81, p.87-95, 2005.

ELFSTRAND, S.; BATH, B.; MARTENSSON, A. Influence of various forms of green manure amendment on soil microbial community composition, enzyme activity and nutrient levels in leek. Applied Soil Ecology, v.36, p.70-82, 2007.

HOLLINGER, S.E.; BERNACCHI, C.J.; MEYERS, T.P. Carbon budget of mature no-till ecosystem in North Central Region of the United States. Agricultural and Forest Meteorology, v.130, p.59-69, 2005.

LAL, R. Soil carbon dynamics in cropland and rangeland. Environmental Pollution, v.116, p.353-362, 2002.

LARA CABEZAS, W.A.R.; ALVES, B.J.R.; URQUIAGA CABALLERO, S.S.; SANTANA, D.G. de. Influência da cultura antecessora e da adubação nitrogenada na produtividade de milho em sistema plantio direto e solo preparado. Ciência Rural, v.34, p.1005-1013, 2004.

MACHADO, L.A.Z.; ASSIS, P.G.G. de. Produção de palha e forragem por espécies anuais e perenes em sucessão à soja. Pesquisa Agropecuária Brasileira, v.45, p.415-442, 2010.

MACHADO, P.L.O. de; SILVA, C.A. Soil management under no-tillage systems in the tropics with special reference to Brazil. Nutrient Cycling in Agroecosystems, v.61, p.119-130, 2001.

MARCHÃO, R.L.; BECQUER, T.; BRUNET, D.; BALBINO, L.C.; VILELA, L.; BROSSARD, M. Carbon and nitrogen stocks in a Brazilian clayey Oxisol: 13-year effects of integrated crop-livestock management systems. Soil and Tillage Research, v.103, p.442-450, 2009.

MUHR, L.; TARAWALI, S.A.; PETERS, M.; SCHULTZE-KRAFT, R. Forage legumes for improved fallows in agropastoral systems of subhumid West Africa. II. Green manure production and decomposition after incorporation into the soil. Tropical Grasslands, v.33, p.234-244, 1999.

PACHECO, L.P.; LEANDRO, W.M.; MACHADO, P.L.O. de A.; ASSIS, R.L. de; COBUCCI, T.; MADARI, B.E.; PETTER, F.A. Produção de fitomassa e acúmulo e liberação de nutrientes por plantas de cobertura na safrinha. Pesquisa Agropecuária Brasileira, v.46, p.17-25, 2011.

PITOL, C.; BOCH, D.L.; CARVALHO, CARVALHO, A.M. de.; SPERA, S.T. Uso de adubos verdes nos sistemas de produção no bioma Cerrado. In: CARVALHO, A.M. de; AMABILE, R.F. (Ed.). Cerrado: adubação verde. Brasília: Embrapa Cerrados, 2006. p.301-330.

ROBERTSON, J.B.; VAN SOEST, P.J. The detergent system of analysis and its application to human foods. In: JAMES, W.P.T.; THEANDER, O. (Ed.). The analysis of dietary fiber in food. New York: Marcel Dekker, 1981. p.123-158.

SANTOS, H.G. dos; JACOMINE, P.K.T.; ANJOS, L.H.C. dos; OLIVEIRA, V.A. de; OLIVEIRA, J.B. de; COELHO, M.R.; LUMBRERAS, J.F.; CUNHA, T.J.F. (Ed.). Sistema brasileiro de classificação de solos. 2.ed. Rio de Janeiro: Embrapa Solos, 2006. $306 \mathrm{p}$. 
SANTOS, P.F.; WHITFORD, W.G. The efects of microarthropods on litter decomposition in a Chihuazhuan ecosystem. Ecology, v.62, p.654-663, 1981.

SAS INSTITUTE. SAS/STAT: user's guide. Version 8.1. Cary: SAS Institute, 1999-2000. 943p.

SILVA, J.E.; LEMAINSKI, J.; RESK, D.V.S. Perdas de matéria orgânica e suas relações com a capacidade de troca catiônica em solos da região dos Cerrados dos oeste baiano. Revista Brasileira de Ciência do Solo, v.18, p.541-547, 1994.

SODRÉ FILHO, J.; CARDOSO, A.N.; CARMONA, R.; CARVALHO, A.M. de. Fitomassa e cobertura do solo de culturas de sucessão ao milho na região do Cerrado. Pesquisa Agropecuária Brasileira, v.39, p.327-334, 2004.

WAGNER, G.H.; WOLF, D.C. Carbon transformations and soil organic matter formation. In: SYLVIA, D.M.; FUHRMANN, J.J.; HARTEL, P.G.; ZUBERER, D.A. Principles and applications of soil microbiology. New Jersey: Prentice Hall, 1999. p.218-256.

WUTKE, E.B.; TRANI, P.E.;AMBROSANO, E.J.; DRUGOWICH, M.I. Adubação verde no Estado de São Paulo. Campinas: Coordenadoria de Assistência Técnica Integral, 2009. 92p. (CATI. Boletim técnico, 249).

Received on July 23, 2010 and accepted on September 29, 2011 